\title{
Selvets fragmenter
}

\author{
Om Franz Kafkas autobiografiske \\ delbygninger
}

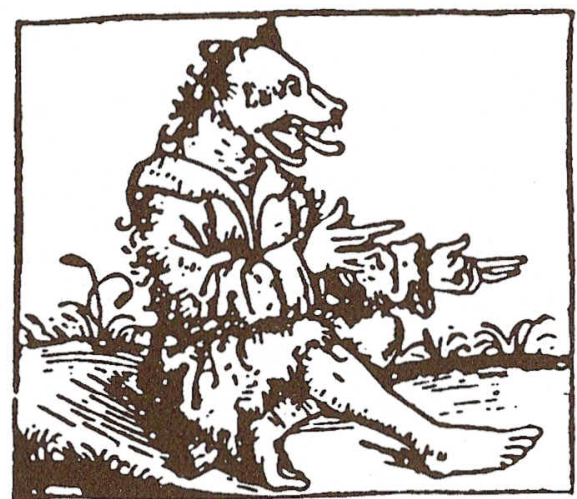

Cynocephate

(Hundehovede )

\section{Christian BANK PEDERSEN}

Man kan kun vanskeligt forestille sig en forfatter mere prekært præsent i sit værk end Franz Kafka - og mindre konventionel i refleksionen af denne autobiografiske udfoldelse eller tænken af forfatteren iværket. De fundamentale udfoldelsesmodi for Kafkas forsøg på at komme overens med Schreiben i selvanalyse er særdeles komplekse og vidt forgrenede: de involverer ikke blot, hvad der synes at præsentere sig som egentlige læsninger af det litterære værk - Kafkas kommentarer til, og refleksioner over, Dommen er måske det mest berømte eksempel på denne bevægelse -, men også oplevelser af at leve i "et lille ord", tanker om at fylde et ord med sig selv, drømmen om at blive "blodsbeslægtet med en sund historie" og, naturligvis, den fantasmatiske forestilling om ikke at være andet end litteratur, om ikke at kunne, eller at ville, være andet end litteratur.1

Til en begyndelse kunne man derfor - også med receptionshistorien in mente - hævde, at det for læseren af Franz Kafkas værk i forskellige perspektiver ikke er muligt ikke at kende den forfatter, hvis værk læses. Derefter kunne man spørge, hvorvidt det er muligt, ilæsning, at glemme forfatteren - dvs. forfatteren som et identificerbart historisk subjekt, til hvilket der kunne knyttes visse biografiske data-præcis via denne markante grad af autobiografisk refleksion. Med andre ord: i Kafkas værk arbejder den autobiografiske form - og med denne sigtes der her på ingen måde til autobiografien som genre - ikke henimod skabelsen af et 
narrativt rum i og igennem hvilket et oplyst og myndigt subjekts totale og kontinuerte erfaring på særlig vis bliver såvel etableret af som repræsenteret for selvet. Igennem skrive akten udvikler og undersøger Kafka ikke sin endegyldige og sikre subjektivitet - og ønsker i sidste ende heller ikke at kende eller blive forbundet med en sådan form. Han initialiserer snarere hvad man, med Roland Barthes' Lq:on, kunne kalde en proces af aflcering - desapprendrez som en form for subjektiv selvbeskæring til og i litteratur. Franz Kafka er aldrig til stede i værket som et Jeg i erindring af en personlig perfektions historie, men decimod som navnet Franz Kafka i, eller som, en vedvarende positionel og temporal transformation.

Et fundamentalt spørgsmål for læsere af Kafka kunne da vedrøre mulige former for glemsel, og således relatere sig til muligheden for at glemme forfatteren på en facon, der bærer et forskudt slægtskab med den måde, hvorpå forfatteren glemmer sig selv i det værk, der, som værk, faktisk ikke skriver andet end forfatteren.

For at forfølge dette spørgsmål må man undersøge relationen mellem på den ene side det litterære værk og på den anden dagbøgerne og optegnelserne. Det er i den forbindelse af væsentlig betydning for læsningen af Franz Kafkas autobiografiske figurationer at denne relation mellem et litterært værk, og hvad der almindeligvis betragtes som et privat dokument, hos Kafka reelt ikke er nogen relation overhovedet - i det mindste ikke, hvis man ved en relation forstår en form for forbindelse mellem veldefinerede og separate entiteter; 'ren' litteratur og 'ren' dagbog som privat form, til eksempel.

Franz Kafkas Tagebiicher blev - i tolv hæfter og på en række løse blade - skrevet fra 1909 til 1923,og rummer fra første færd en særegen udveksling mellem privat optegnelse og litterært eksperiment.. Kafkas dagbog er altid kun lig sig selv (som sådan) i dens væren forskellig fra sig selv (som sådan). Dette er faktisk også, hvad der skrives i og omkring forfatterens dagbøger og optegnelser: En allegorisk Krydsning, til eksempel.. I foråret $1917 \mathrm{skrev}$ Kafka et lille prosastykke med titlen "Eine Kreuzung". Det begynder:
Jeg har et ejendommeligtdyr, halvt killing, halvt lam. Det er et arvestykke fra min faders ejendom,udviklet har det sig dog førsti min tid, tidligerevar det megetmere lam end killing,men nu har det vel afbegge lige meget. Af katten hovede og kløer, af lammet størrelse og form, a begge øjnene,der er flakkendeog milde, pelsenshår, der er blødt og ligger tæt, bevægelserne,der er såvel hoppen som listen [sowohlHiipfen als Schleichen],..(GWb,d. 6: Beim Bau der chinesischen Mauer und andere Schriften aus dem Nachlass, p. 92)

Dette kreatur - der ikke engang er en bastard, og om hvilket fortælleren bemærker, at det "slet ikke kan skilles fra mig" - er i sandhed et særegent arvestykke at modtage fra sin fader. De traditionelle former, hvoraf det synes at være dannet, er næsten for traditionelle til stadig at kunne eksistere i og for sig selv som separate figurer: halvt kat, halvt lam, dels dette, dels hint, et konventionelt. symbol og emblem i dets væren også et andet. Denne Kreuzung er på en og samme tid vild, listig og kødædende og mild, tillidsfuld, ren, uskyldig og græsædende. Men det vil nærmere betragtet sige: det er den ikke, for der er reelt ikke noget $o g$, der binder figurens, eller sætningens, dele sammen i Kafkas Krydsning, der som skabning netop ikke er nogen syntetisk forsoning af modsætninger. Den er snarere en kafkask Unding, der ville jage livet af sig og selvdestruere - æde sit eget kød, der ikke æder kød, og dermed udøve en dødelig Hungerkunst i den mest bogstavelige forstand -, havde den ikke præcis i en paradoksal forvrængning været så forskellig fra sig selv: som Krydsning kun 'sig selv' i dens væren 'andet'. Og havde ikke dens dele, der ikke er dens dele, som dele, været forskellige fra det, de er: "...vor Katzen flieht es, Uimmer will es anfallen ...", "...for katte flygter den, lam vil den overfalde ..." (ibid., p. 92), som fortælleren beretter det efterfølgende.

Hvordan bevæger denne Kreuzung sig? Hvordan kommer den fra det ene sted til det andet? Med bevægelser "...die sowohl Hupfen als Schleichen sind...", med bevægelser, der på samme tid er en hoppen og en snigen eller listen. På hvilken måde, præcis, forventes læseren at forestille sig denne form for "Bewegung", denne form for traditionelt synlig udfoldelse? Krydsningens bevægelser synes af en art, der kun særdeles vanskeligt, om 
overhovedet, lader sig beskrive i deres totalitet som en bevægelse. Og dog er det en bevægelse: de "Bewegungen", der bringer krydsningen omkring, er en form for udfoldelse, der på en gang er såvel en hoppen - dvs. små abrupte og diskontinuerte spring som en snigen eller listen - dvs. en langsom, skjult, kontinuert og glidende bevægelse. Ikke ulig krydsningen selv gestalter dens bevægelsesform sig således som sin egen umulighed: som en bevægelse, der ikke blot er to, men ret beset to elementært modsatrettede former for bevægelse, der gensidigt udelukker hinanden: hvis der er "Hiipfen", kan der ikke være "Schleichen", og hvis der er "Schleichen", kan der ikke være "Hiipfen". Dette er ikke desto mindre netop, hvad der er, eftersom det simpelthen er på denne vis Eine Kreuzung præsenterer sig selv. Anderledes sagt og netop med en bevægelse, der er såvel hïpfend som schleichend: hvis der er dagbog og privat tale eller dokument, kan der ikke samtidig være litteratur, og hvis der er litteratur, kan der ikke samtidig være dagbog og privat tale eller dokument.. Men, igen, der er: dette er hvad hoender i Kafkas værk.. Forudsat at "Eine Kreuzung" kan læses som en allegori, en krydsning af en krydsning, på den skriven - halvt Tagebuch, halvt Literatur -, der viser sig i Kafkas gestaltninger.

Det var ikke usædvanligt for Kafka at lade de hæfter, der skulle anvendes til dagbogen, og de hæfter, der skulle bruges til optegnelser og litterært arbejde, gennemtrænge hinanden - og træde i stedet for hinanden - i en meget ligefrem forstand: I 1909 , for at tage et eksempel fra hans tidlige forfatterskab, begyndte han således et hæfte af optegnelser, der skulle *ne som et eksklusivt sted for litterær virksomahed, og dermed danne en strikt parallel til det første dagbogshæfte, der ligeledes blev påbegyndt i 1909. Men et år senere blev dette optegnelseshæfte faktisk forvandlet til intet andet end netop en dagbog, der igen blev anvendt afvekslende med det første, originale, Tagebuchheft, indtil det, i marts 1911,blev transformeret tilbage til et 'rent' sted for litteratur. Kafka fortsatte da med at skrive sin 'egentlige' dagbog i det første hæfte - og videreførte den i et tredje.

Det ser på den vis ud til, at Kafka bestandig flyttede sig omkring mellem forskellige, men alligevel sært sammenfaldende, åsteder for sin skriven - oftest uden at afslutte, hvad han altid var $\mathrm{i}$ færd med at begynde. Anledningen til disse bevægelser var ikke sjældent blokeringer i skriveprocessen, der igennem denne stadige omlokalisering netop ikke skulle 'overvindes' - i den mere simple og lidt mærkværdigt martialske forstand - men derimod snarere reflekterende iværksættes som sådanne i selve bevægeligheden mellem steder for Schreiben.

Et sidste eksempel: i februar 1913begyndte Kafka sit syvende dagbogshæfte, som han fortsatte med at anvende indtil maj, hvor han efterlod det ufærdigt. Han begyndte da at skrive sit ottende Heft, som han afsluttede i februar måned 1914,hvor han efterfø1gende vendte tilbage til det ufuldendte syvende dagbogshæfte. Denne nye begyndelse antog en særlig form, idet Kafka faktisk ikke vendte tilbage til det punkt, hvor han tidligere slap, men derimod begyndte i den anden ende af hæftet, hvorffra bevægelserne mod litterært eksperimenterende former blev flere og flere. Kafka vendte således i mere end en, bogstavelig, henseende sin dagbog på hovedet, og det syvende hæfte slutter i august 1914 med et fragment af den tekst, der kendes som "Erinnerungen an die Kaldabahn.".

Man kan betragte disse selvforskydninger fra Franz Kafkas hånd - hans tendens til konstant at lade sig deplacere i det egne materiale - itilknytıing til en tekst, han arbejdede på i 1917:Fragmentet "BeimBau der chinesischen Mauer" åbnes med en eksposition af hvad der kaldes "System des Teilbaues", "delbygningens system":

Den kinesiske mur er blevet afsluttet i dens nordligste punkt.. Fra sydøst og sydvest blev bygaingen ført frem og forenet her. Dette delbygningens system blev også fulgt $\mathrm{i}$ det små inden for de to store arbejdshære, østog vesthæren. Dette gik for sig således, at der blev dannet grupper bestående af omkring tyve arbejdere; som skulle opføre en delmur' af omkring femhundrede meters længde, en nabogruppe byggede dem da en mur' i samme længde i møde. Men efter at foreningen var blevet fuldbyrdet, blev bygningen dog ikke fortsat ved enden af disse tusind meter, tværtjmod blevarbejdsgrupperne igen sendt bort til murbygning i helt andre egne. Naturligvis opstod på denne vis mange store huller, der kun lidt efter lidt langsomt blev udfyldt, mange endda først efter at murbygningen allerede var forkyndt som fuldendt. Ja der skal findes huller, der 
overhovedet ikke er blevet lukket....[Natiirlichentstanden auf diese Weiseviele grosse Liicken, die erst nach und nach langsam ausgefull wurden, manche sogarerst nachdem der Mauerbau schon als vollendet verkiindigt worden war. Ja es solI Liickengeben, die iiberhaupt nicht verbaut worden sind...) (GW:bd. 6:Beim Bau der chinesischen Mauer ..., p. $65)$

Hvilken form for modstand denne mur kunne tænkes at byde en udefrakommende, lader sig kun vanskeligt bestemme - og en eventuel bestemmelse forudsætter naturligvis i det hele taget, at et udefra overhovedet kan defineres i forhold til denne bemærkelsesværdige kinesiske mur. At dette langt fra er sikkert lader sig også se, når man tager den mere eller mindre idiomatiske vending gegen eine Mauer rennen i betragtning. At løbe panden mod denne mur hos Kafka indebærer jo reelt muligheden for, såvel bogstaveligt som metaforisk, at løbe direkte igennem dens konstitutive huller, uden at møde den som hindring - at ende, sagt på lidt anden vis, ved dens ikke-eksisterende anden side, uden at være i stand til at afgøre om denne mulighed er en chance for et forstående overblik eller en risiko for helt og holdent at miste et eventuelt. sådant. Kafka synes altid at bygge i to, og den altid ufærdige kinesiske mur er dannet af to overordnede enheder, hvis bygningsprincip siges at blive gentaget $\mathrm{i}$ deres indre af de mindre enheder, der skulle forme deres helhed: to grupper af arbejdere bygger de mindre enheder ved at arbejde sig frem mod hverandre fra hver sin ende, og bliver derefter, når mødet i midten er fuldført, overført til andre dele, hvor de viderefører det diskontinuerte arbejde.

I "Beim Bau der chinesischen Mauer" tænkes dette værk af nogen ind i en større mytologisk forhistorie: den kinesiske mur siges at skulle danne, eller at skulle udvikle sig til, fundamentet for et nyt Babelstårn. Fortælleren er ikke i stand til fuldstændigt at begribe denne konception: "Das konnte doch nur in geistiger Hinsicht gemeint sein." - "Det kunne da kun være menti i en åndelig henseende." (ibid., p. 69). Måske er det da også blot i geistiger Hinsicht, at fundamentet for det nye Babelstårn kan læses som det skrivende subjekt, hvis ender ikke mødes i den skrift, i hvil- ken det søger at præsentere sig, at stille sigfrem. ${ }^{3}$ Kafkas værkhæren af dagbøger og hæren af litteratur - bevæger sig ved at bevæge sig tveformet, fra modsatte ender, mod en midte og en fuldstændiggørelse, der kun, hvis nogensinde, opnås lokalt. Og eftersom at fortsætte er at sende, eller at blive sendt, bort, og videreførelse dermed forskydning - så snart udførelsen af en mindre enhed eller et fragment er tilendebragt,, bliyer forfatteren af værket overført til bygningen af en anden del, der ikke kan afgøre, hvilken totalitet den er del af, eftersom helheden kun gives som sin egen delte deling.

Hvilken besynderlig mise en abfme er på færde her? At læse denne tekst, "Vedbygningen af den kinesiske mur", viser den enkelte enheds rum og temporalitet som værende altid out of joint, i det øjeblik hvor, eller når, den udfolder sig, og betragtes, som en refleksion af forfatterens værk.. Man kunne derfor sige, at hvad der eksponeres her, er den diskontimuerte relation mellem singulære enheder, der kun gives som sådanne i kraft af den perfekte totalitet, de $i k k e$ producerer. Fortællingen "BeimBau der chinesischen Mauer" repræsenterer ikke dette kompleks: den er selv i die Liicke, i lakunen, som en fragmentarisk præsentation af det fragmentariske værk, i hvilket den eksisterer som fragment.. Det skrivende selvs lakuner kan øjensynligt kun fyldes af den skriven, der udvider dem, ligesom muren kun er kohærent i kraft af sine huller. Totaliteten, eller forestillingen om den, kan kun findes, og finde sted, i hullet: det, der på en gang undslipper den og konstituerer dens mulighed. Med andre ord: lakunen mellem liv og værk kunne hos Kafka siges at være værket selv.

Alt dette er selvsagt ment i geistiger Hinsicht. Men i Franz Kafkas forfatterskab findes der altid en særdeles sanselig udfoldelse af enhver spirituel intention. Mod slutaingen af den citerede begyndelse af "Vedbygningen af den kinesiske mur" lyder det således på en særlig vis: "Natiirlich entstanden auf diese Weise viele grosse Liicken, die erst nach und nach langsam ausgefiillt wurden, manche sogar erst nachdem der Mauerbau schon als vollendet verkiindigt worden war. Ja es solI Liicken geben, die iiberhaupt nicht verbaut worden sind..." Det lyder her ganske bogstaveligt som om singulære enheder arbejdede sig frem mod 
en enhedslig sætning af en, i alle henseender, ligefrem hel-mening: den første sætning ender i en form for rytmisk harmoni mellem $v$ og $w$ : "vollendet verkiindigt worden war." Men en omvending af denne dobbelte harmoni går faktisk forud for den: "Natiirlich entstanden auf diese Weise viele grosse Liicken." Og denne omvending bliver igen vendt om i den efterfølgende sætning, her halvt citeret: "es soll Liicken geben, die iiberhaupt nicht verbaut worden sind." Også netop på denne vis opstår mange store, hørbare, huller, der hverken kan, skal eller vil lukkes i frembringelsen af en formens uplettede totalitet: afbrydelsen, disse Liicken, er ikke blot bestandig nærværende, men også altid gjort, og i færd med at gфres, i selve værkets korporligt sanselige udfoldelse, i dets virken og selvfremstilling.

Der findes altså ingen perfekt og enhedslig harmoni i disse bogstaver - og da slet ikke i åndelig henseende: identiske dele gentages som forskellige i altid forskellig orden på vej mod en Ganzheit, der aldrig nås. Ikke engang det enkelte, formodet selvidentiske bogstav, er i overenstemmeise med sig selv i nogen ligefremt positiv forstand: fuldendelse, Vollendung, er blot forkyndelse, Verkiindung, og helhedens 'bogstav' kan da siges kun at rime med den fantasmatisk-ironiske udtalelse af dets fuldstændiggørelse. Med dette som baggrund kan man på ny læse sætningen: "Das konnte doch nur in geistiger Hinsicht gemeint sein." Hvad siger den? Måske også, at ifald noget ikke er "in geistiger Hinsicht" er det ikke "gemeint" i en direkte, kommunikativ forstand, og at ifald noget ikke er ment, er det ikke "in geistiger Hinsicht", men simpelthen til stede - i den taktile fremstilling af noget andet. Værket er således måske hverken mere eller mindre end den leende drøm om sin egen totalitet.

Dette kan bringe en frem til en passage i Kafkas dagbog, fra december 1911, hvori relationen, der ikke er nogen relation, mellem dagbogens og den litterære frembringeises form manifesterer sig på en signifikant facon:

16. <17.> XII <1911> Lørdag [el, søndag] kl, 12 middag. Formiddagen klattet bort med søvn og avislæsning. Angst for at færdigg øre en anmeldelse til "Prager Tagblatt". En sådan angst for at skrive [vor dem Schreiben) ytrer sig altid deri, at jeg lejlighedsvis uden at være ved skrivebor- det, opfinder indgangssætninger til det der skal skrives; indgangssætninger, der straks viser sig som ubrugelige, tørre, afbrudt langt før enden, og som med deres fremtrædende brudsteder [Bruchstellen] peger ind i en sørgelig fremtid. (GW,bd. 9: Tagebucher 1909-1912,p. 229)

Hvor begynder litteraturen, den egentlige Schreiben, for Franz Kafka? Til eksempel i forhold til en form for skriven, der kun gives som sådan i dens gåen bort som sådan; en form for skriven, der bliver brugt, og bruges $o p$, tømmes, idet den læses, eftersom den kun eksisterer for at pege bort fra sig selv - 'ud' mod det, der kaldes dagens begivenheder: 'nyheder'? Præcis opgaven for avisen "das Prager Tagblatt" - og dermed en opgave for et medium, hvori ordene og formen i en vis henseende har overlevet sig selv, og bliver klattet bort, "vertrodelt", hvert øjeblik - er for Kafka situationen for en betragtning af litterær form overhovedet. Denne bevægelse er karakteristisk:. den partikulære begivenhed fører hos Kafka altid over i et spørgsmål om das Schreiben som sådan. Eller rettere: den partikulære situation er, for at bruge notatets egen og væsentligste figur, et brudsted, Bruchstelle, for en refleksion af det litterære i en større kontekst: angst for at skrive manifesterer sig altid på en særlig måde, nemlig idet forfatteren opfinder indgangs- eller åbningssætninger, Eingangssiitze, til det, der skal skrives i fremtiden - "...alles geschah mir fUrimmer...", "...alting hændte mig for altid...", skriver Kafka i et andet dagbogsnotat. ${ }^{4}$

At være uden for skrivebordets domæne er øjensyruigt på en vis facon også at være inden for skrivebordets domæne. Angst for, eller måske foran, skriven - angst for måske ikke at være stand til at komme ind - manifesterer sig i opfindelsen af indgangssætninger til det, der må skrives, dvs. som præcis det, angsten er rettet imod: man kunne derfor sige, at angst for ikke at kunne komme ind i Schreiben, er angst for allerede at være der, for aldrig, som Franz Kafka, at være udenfor. I det moment hvor Kafka i angst står foran skrivningen, er han trådt ind i, og træder han ind i, das Schreiben - som dermed præsenterer sig som brudsted for sig selv, som sin egen revne eller fraktur. Skriven for Kafka ser således ud til at være sin egen fold; en fold, der befin- 
der sig hinsides repræsentation, er det, der kun kan nås - i en vedvarende omskrivning -, som sin egen afbrydelse, og kun viser sig i fragmentariske former, der, såvel tidsligt som rumligt, peger i retning af yderligere fragmentarisering - ikke mindst af forfatteren i skriveakten.

En af Kafkas mest berømte Eingangssiitze reflekterer ligeledes over ankomstens problem - eller over spørgsmålet om at ankomme -, og dermed over spørgsmålet om, hvor og hvordan et enkelt, skrivende subjekts partikulære frembringelser kunne siges at stå i forhold til litterær aktivitet i en mere generel betragtning: "Es war spat abend als K ankam."5 Dette er den første sætning i romanen Das Schloss, som Kafka begyndte at skrive i foråret 1922,men aldrig færdiggjorde. Forud for en overvejelse af de mulige perspektiver i netop denne åbning af romanen, kunne en kort betragtning af dens titel være af interesse: det tyske substantiv Schloss betegner ikke blot en mere eller mindre veldefineret arkitektonisk form, men også en lås. Denne sidste betydning er forbundet med, hvad man kunne kalde verbale former for åbning og lukning: etwas einschliessen, at inkludere noget, eller 'at åbne op for noget for at lukke sammen om det'; etwas ausschliessen, at udelukke noget; etwas/sich verschliessen, at låse, eller lukke, noget eller sig selv; og, ikke mindst vigtigt, sich (fUr etwas) entschliessen, at beslutte sig, at beslutte sig for noget, eller bogstaveligt: at aflåse sig selv, at åbne sig selv (for eller mod noget).

Den første sætning i en tekst er, selvsagt, dens åbning: tidsligt, rumaligt, i relation til enhver tænkelig læser, og, per definition, for og af forfatteren. Derfor kunne en teksts åbningssætning også, qua dens; væren udgangspunkt, kaldes for tekstens; originale beslutning: dens Entschluss og dens, i et særligt perspektiv, selvgenererende oprindelse, der i dens bliven iværksat som begyndelse, åbning og oprindelse for alt kommende, naturligvis også virker som grænse for, hvad der kan komme; dvs. som åbning også virker ved at indsnævre, ved at bestemme og begrænse de mulige veje for udfoldelse.

Betragtet i den elementære kontekst er den første sætning Das Schloss særegen: "Es war spat abend als K ankam." I denne sætning er den essentielle bevægelse ankomstens: ad forskellige veje, og forskudt fra hinanden, ankommer ikke blot K, men også læseren og romanen, der er bevægelsen i sig selv, $i$ sætningen: "Det var sen aften da K ankom." Men hvis noget der nærmer sig sikkert overhovedet kan siges om den tekstuelle bevægelse i Slottet, må det næsten være, at præcis Ks vedvarende stræben efter at ankomme i, eller til, det fantastiske rum, der har givet romanen dens titel, er bundet i fejlslag hvert eneste øjeblik. I Das Schloss lukker alt sig sammen om den - K, naturligvis --, der udelukkes, og som udelukker sig selv, i et humoristisk konglomerat af fejlfortolkninger, omhyggeligt latterlige forsøg på forklaring, og, til dels villet, gensidig misforståelse. Et konglomerat, der selvfølgelig er romanen selv.

Det er derfor iøjnefaldende vigtigt, at $\mathrm{K}$ i romanens absolutte begyndelse træder frem som stående ved siden af præteritumsformen af verbet ankommen. Men $\mathrm{K}$ står ikke blot ved siden af, og dermed uden for, denne ankomst; han er også bundet i dens midte, på samme tid inden for og uden for en fortidig entre, eftersom sætningen jo lyder "Es war spat abend als $K_{\text {. }}$ ankam." Igennem konsonanternes klang gestaltes en særlig form for rytmisk Witz, i det moment hvor romanen om ankomstens umuligheder åbner sig for den læser, der ankommer øverst på siden. K er dermed fra begyndelsen bogstaveligt lukket inde, eingeschlossen, i det verbum, der ikke beskriver hans bevægelse i Slottets sfære, og hovedpersonen bliver på den måde bogstavet i midten af et ord, der aldrig realiseres som den handling, det markerer. Protagonisten er således som form en art indfoldet dobbelthed: som figur finder han sted i præcis det, han. ikke fuldender.

Men enhver overvejelse af en mulig midte i tilknytning til Das Schloss må tage ankomstens ironi i betragtning: det er jo netop prekært overhovedet at berøre midten som andet end en anfægtet mulighed i forhold til en roman, hvis begyndelse splitter sig selv, i mere end et perspektiv, og hvis afslutning aldrig kommer. Den første sætning i Slottet etablerer og markerer implicit dels en ankomst, der ikke er, og aldrig vil blive, en ankomst, dels en hovedperson, K, der, idet han begynder i denne sætning, begynder idet han splittes i en repetition: som rytme - "K.. ankam" - er figuren eller bogstavet (forskellen består i det forkortelsesangivende 
punkt) splittet i to, og K. dermed udspændt mellem betydning og physis. K. rimer uomtvisteligt i begyndelsen - bare ikke med sig selv. Navnet - og at det er et navn signaleres netop via det forkortelsesmarkerende punktum - kunne da siges at være splittet på to forbundne måder: på den ep.eside er det kløvet, delt, idet det er beskåret, og på den anden fremstilles det som en form, der kun kan manifestere sig som splittet, eller som splittelsen, mellem mening og physis, mellem betegnelse og rytmisk klang - eller 'ren' taktil tilstedeværelse. Det kan derfor heller aldrig blive skildret, meddelt, som andet end præcis denne splittelse, og derfor aldrig fortælles som selvidentisk totalitet.

Franz Kafkas indgangssætning udgør på den vis en form for tekstens Ursprung - i Benjamins konception af ordet: en åbning og en oprindelse, der sætter eller initierer en temporal udfoldelse, og bringer den til stivnen i en og samme bevægelse, og således en åbning, der markerer en intim gensidig afhængighed mellem singularitet og gentagelse - "Einmaligkeit und Wiederholung"6i oprindelsen selv. Igen anderledes sagt: som åbning også er en Ur-Sprung, et knæk eller en sprække i og som begyndelsen selv mellem $\mathrm{K}_{.}$og ..k.. -, der frembringer $\mathrm{K}$ som bestemt af begyndeIsens andethed, af en fundamental forskel fra sig selv. At K er bundet $\mathrm{i}$ midten af ankomsten, $\mathrm{i}$ en bevægelse, der brydes $\mathrm{i}$ sin egen udfoldelse, betyder derfor, at han står i en midte, der kun findes som forskudt i Slottets rum: hvad angår spørgsmålet om ankomst, findes der ikke nogen ren begyndelse eller slutning, men kun åbningens gentagne imellem.

For K lader det altså til, at det første skridt frem er skridtet tilbage - $\mathrm{i}$ den rytmiske kløvning af bogstavet i en repetition, der ligeledes markerer en deplacering i relation til Ks tilsyneladende mest fundamentale begær: at ankomme fuldt ud. At forbindelsen mellem K og k i en mere omfattende henseende er både for tæt ogfor fjern for forfatteren, vidner Kafkas værk i det hele taget om. For Kafka er skridtet ind i værket også altid skridtet tilbage fra det - i en stadig refleksion over muligheden for at falde sammen med sit eget navn, eller sit eget bogstav, i skriven. At træde ind i litteraturen er for Kafka at insistere på diverse forskelle i gentagelsen - af sig selv. K stemmer ikke fuldt ud overens med sig selv
- eller for den sags skyld med $k$ i "ankam" -, og Kafka er ikke identisk med $\mathrm{K}$ Men anderledes betragtet er han ikke i stand til at tænke sig selv som andet: i sidste ende er det, der må reflekteres, spørgsmålet om, hvordan man kan siges at falde sammen med det, man altid adskiller sig fra.

Nogle mulige betydninger i lyden af et $\mathrm{K}$, der gentages $\mathrm{i}$ begyndelsen af et værk, kan ses igennem et perspektivrigt notat fra Kafkas dagbog, der stammer fra tiden omkring forfatterens første forlovelse med Felice Bauer. Eftersom moderen og søsteren er i Berlin for at forberede den officielleforlovelse, må Kafka forberede sig på en aften isoleret med faderen i hjemmet.. Det gør han, naturligvis, i dagbogsform:

27. V 14 Moder og søster i Berlin. Jeg bliver alene med fader [dem Vater] $i$ aften. Jeg tror han er bange for at komme herop. Skal jeg spille kort med ham? (Jeg finder K'eme [die K] hæslige, de er mig næsten modbydelige og jeg skriver dem alligevel, de må være meget karakteristiske for mig) Hvordan fader [der Vater] forholdt sig, da jeg berørte F. (GW, bd. 10 Tagebiicher 1912-1914, p. 145)

Et interessant kompleks af forskudte tautologier udfoldes i denne passage fra Kafkas dagbog. Tilen begyndelse kunne man bemærke, hvordan notatet næsten synes at omskrive et univers, der ligger hinsides, eller ved siden af, den intime sfære, som forfatteren umiddelbart berører. Dette er en anelse paradoksalt, eftersom Kafka reelt ikke skildrer noget ud over det, der er særdeles tæt forbundet med ham, og af afgørende betydning for hans fremtidige bevægelser - i en materiel såvel som følelsesmæssig henseende. Paradokset hidrører fra den let besynderlige kadence, der etableres ad to veje i notatet, dels via dets pronomener, dels via dets grad af grammatisk bestemthed: hvorfor skal Kafka denne aften ikke være alene med Vater, men med "dem Vater"? og hvorfor er det ikke mein $K$, men "die K", der synes at være næsten frastødende? og hvorfor er det ikke Vater, men Ilder Vater", der forholder sig på en særlig - ubeskrevet - facon, i det øjeblik Kafka berører "F." - som i øvrigt, naturligvis, er Felice Bauer? 
Selvom disse grammatiske former ikke som sådanne kan siges at være helt og holdent usædvanlige, manifesterer de ikke desto mindre et specifikt - og besynderligt - rum af distance og fysisk og emotionel forskydning i en skriven, der i eminent grad vedrører sanselig tilstedeværelse og taktile relationer: Kafka skal for en tid være alene med faderen i det hjem, han deler med forældrene, og kan derfor se frem til en direkte udveksling og kontakt med denne; han er omtrent fysisk frastødt af sin egen håndskrifts $K$, der dels er ekstremt synligt, dels selvsagt er nærværende her i selve sin tilblivelse; han har berørt E, og han har set, at faderen så denne berøring - og åbenbart reagerede på en bestemt facon, der udelukkes i og af notatets bevægelse. Kafka relaterer med andre ord sanselig udveksling og berøring i, og med, en form for skriven, der ikke blot på særlig vis lever af en distance til præcis de taktile kontakter, der bliver fremstillet eller omskrevet, men også, i dens bliven skrevet, bliver opmærksom på sig selv som en meget fysisk realitet, der, igen på en særlig facon, distancerer sig fra den, der skriver.

Der synes altså ret beset at være mere end en parentes på færde i Kafkas notat: I midten af optegnelsen kan man firide en parentes om bogstavet $\mathrm{K}$, ikke som det præsenterer sig som et uforanderligt element i alfabetet, men som det træder frem i Kafkas egen håndskrift. Denne parentes er omringet af to betragtninger vedrørende faderen, Hermann. Kafka, og forskellige former for fysisk kontakt:. på den ene side kontemplerer Kafka situationen, at han i den meget nære fremtid skal være alene med sin fader, og forestiller sig i den sammenhæng en mulig angst for netop dette - vel at mærke ikke hos sig selv, men en mulig Furcht hos faderen. På den anden side reflekteres denne kontakt med faderen i relation til en tredje, "E", som Kafka har berørt - og berører i sin optegnelse. Disse betragtninger af varierede former for samkvem etablerer dermed en yderligere klammesætning i forhold til Kafkas parentes om det K, han ikke holder af at se - i det mindste ikke i sin egen håndskrift, der ser således ud:

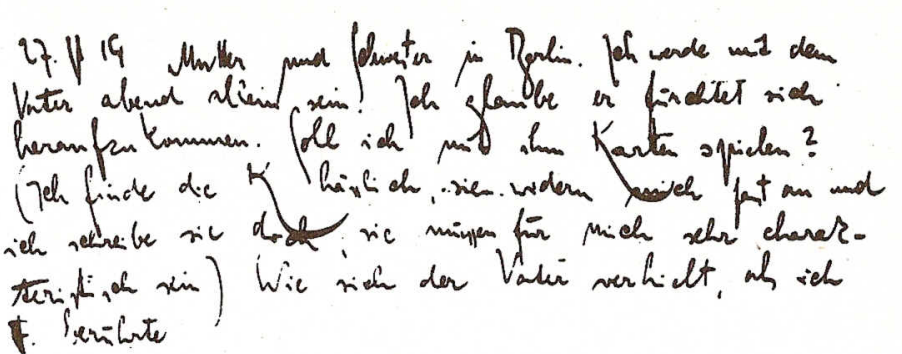

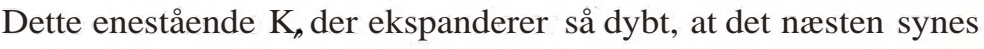
at danne en form for sikkerhedsnet for de ord og bogstaver, der følger efter det, bliver således gentaget af Kafka i netop det moment, hvor han noterer, at det - næsten - byder ham imod. Præcis den bevægelse er karakteristisk i alle henseender. Det næsten frastødende $\mathrm{K}$ træder derudover frem som virksomt på flere niveauer: på den ene side ser det ud som om K'et, i kraft af sin dybt svungne form, omtrent er i stand til at opretholde, eller gribe, de bogstaver, der følger efter det - eller som om det er til for at holde dem på plads; og på den anden side rækker det, post scriptum, forstyrrende ind i det ord, der ligger under det i den følgende linie; eller rettere: ordet under K'et lader sig blive forstyrret og brudt af det. Sånår Kafka i tilknytning til sin håndskrifts K skriver "...sie widern mich fast an und ich schreibe sie doch...", stedfæster han reelt mere end en idiosynkrasi i konventionel forstand: Kafkas K byder ikke kun naesten "mich" imod, eftersom pronomenet, "mig", jo simpelthen bliver skrevet ind i det $\mathrm{K}_{\text {, der }}$ siges, næsten, at arbejde imod det. Det ord, der i sandh $\sim$ er mest ens eget, "mich", synes på den måde at blive til ved at lade sig berøre af det, der både frastøder det, og yder modstand mod det. K er dermed i høj grad det bogstav, der altid alligevel bliver skrevet - og netop "doch" er det andet ord, der lader sig bryde i det. Det lader således til, at Jeg bliver bekræftet ved at skrive mig ind i, og bogstaveligt hen over, det, der på den ene side er karakteristisk for intet andet end 'mig', og på den anden er det, der arbejder mest insisterende imod 'mig'. K er hvad 'Jeg' synes at gøre mod 'mig', idet der skrives, men 'Jeg' er ikke idet K, 'Jeg' skriver "mich" ind 
i - i det øjeblik, hvor det i skrivningen viser sig som det, der virker ved at yde modstand mod 'mig'.

Der er en anden bevægelsesmulighed til stede i Kafkas K: et af hjemmets mest almindelige irritationsmomenter var for Franz Kafka de lyde og bevægelser, der hver aften kom fra forældrenes tilsyneladende evige kortspil - og i særdeleshed fra faderen. Kafka selv spillede ikke kort, og det er derfor, i alle perspektiver, faderensi spil, Kafka - via Verschiebung - træder ind i, idet han forestiller sig en mulig neutral grund for udveksling dem imellem: „,501 lich mit ihm Karten spielen?". Det er således også helt ligefremt $i$ dette spil, at den mere basale udveksling mellem Hermann og Franz Kafka implicit gør sig mærkbar som fragment: familiens navn givet fra fader til søn som ethvert andet patronymikon.

At træde ind $\mathrm{i}$ et kortspil er at lade sig binde i et sæt mere eller mindre faste regler, der går forud for ens entre. Dette elementære træk er i Kafkas situation forbundet med andre former for Spiel, der dels træder $i$ stedet for den skrivende, dels etablerer det eneste mulige grundlag for, at den, der skriver, kan manifestere sig som den, der skriver: navnet Kafka findes i en form for pindig tilstedeværelse som uudtalt: fragment i Kafkas notat, og det gør det præcis i kraft af det, der faktisk ikke kan navngives fuldt ud af den skrivende Franz Kafka: det skrevne K.

Eftersom Kafka ikke slipper uden om at skrive dette $\mathrm{K}$, må det, som han siger, være meget karakteristisk for ham. Med andre, mere leksikalske, ord: dette $\mathrm{K}$, hans $\mathrm{K}$, er noget, der på speciel vis særpræger forfatteren til forskel fra andre st $\varnothing \sim$ relser, andre tilstedeværeiser. Men når man. læser dagbogsnotatet, ser det ud til, at det karakteristiske snarere er noget, der ad besynderlige veje særpræger forfatteren til forskel fra sig selv: "...(lch finde die $\mathrm{K}$ hasslich, sie widern mich fast an und ich schreibe sie doch, sie miissen fiir mich sehr charakteristisch sein)...". Character betyder oprindeligt et indridset tegn eller mærke, hvorved noget kan skelnes fra noget andet; et skrevet tegn, et hemmeligt tegn, eller, simpelthen, et bogstav. Overvejet i den kontekst kan bogstavet K i udpræget grad siges at være karakteristisk for Kafka, idet det jo dukker op selv der, hvor det faktisk ikke er til stede som K - i præ- cis ordet "charakteristisch" omkring hvilket en særegent selvbekræftende prædikativ struktur synes at være virksom -, og dermed lader til at være så effektfuldt, at det sågar evner at gentage sig selv, hinsides kontrol, som noget' andet' end sig selv.

At K "må være meget karakteristisk for mig" kunne derfor også hemmeligt betyde, at det ligner et bogstav eller tegn , for mig", "fUr mich": at det er noget, der bestandig træder i stedet for 'mig', tager 'min' plads, i 'min' litteratur. K er da "charakteristisch fur mich", men det er, så at sige, ikke mindre karakteristisk for 'sig selv', forstået på den måde, at det er en characters character: et skjult tegn' for' et bogstav, der åbenbart bliver ved med at skrive sig selv, og derfor også udgør et singulært træk, der ikke kan gentages, men faktisk kun viser sig som det, der bliver gentaget. Franz Kafka bliver i sidste ende stødt bort og forskudt tiltrukket af intet mindre end sin egen fysiske tilstedeværelse i det skrevne, af selve tegnet på, eller for, hans væren $i$ det, der frembringes. At træde ind i dette Kartenspiel er så for Kafka at træde ind i et spil, som han ikke kontrollerer, men det er også at træde ind $i$ et spil, der reelt ikke præsenterer andet end den forfatter, der ikke behersker det. Det er et autobiografisk spil i den forstand, at det automatisk skriver forfatteren.

K er tilsyneladende i alle aspekter et bogstav, der kun ankommer som splittet, ikke kan fuldføres som begyndelsen til et navn, men altid griber forfatteren $i$ at skrive ved siden af sin egen oprindelse. Apropos en sådan kan man vende tilbage til begyndelsen af Slottet: at det er "spat abend als K. ankam" gælder ligeledes for disse autobiografiske markeringer fra forfatterens hånd, der aldrig repræsenterer en fuldendt subjektiv form i deres binden forfatteren i en metonymisk repetition af tegnet $f U r$ sich: Det er altid sent på aftenen når $\mathrm{K}$. ankommer - tidsligt og rumligt spaltet -, og Kafka satte sig altid ved sit skrivebord ved ellevetiden om aftenen for at arbejde på sine sjældent afsluttede manuskripter til klokken tre eller fire om morgenen. K, ankommer da, uden at ankomme, i selvsamme $\varnothing$ jeblik $K$, uden at gøre det, ankommer øverst på den side, hvor han skriver sit bogstav - og faktisk må forudsætte at ankomsten kun finder sted som en fragmentarisk bevægelse, der er konstitutiv for das Schreiben 
overhovedet. Om sætningen „Es war spät abend als K. ankam” er en mise en abîme af værket, det fragmentariske forfatterskab, eller om værket er en mise en abîme af denne første sætning, er faktisk den eneste tvivl som Franz Kafka, $i$ værket, befinder sig hinsides - i den nietzscheanske forstand. Sætningen er i sig selv splittet, suspenderet på tærsklen, og aldrig ankommende fuldt ud som begyndelsen til en roman.

Den modbydelighed og modstand der er intimt forbundet med det K, Kafka skriver, kunne muligvis også komme til syne i en anden form: Omtrent hver og én af de faderfigurer, der optræder i Kafkas forfatterskab er fysisk frastødende, uhygiejniske og plettede skabninger. Dette træk gør sig ikke mindst gældende i en af forfatterens mest humoristiske autobiografiske konceptioner: fortællingen Das Urteil synes ved første øjekast at fremstille den mest overvældende, magtfulde og dømmekraftige Vater $\mathrm{i}$ Kafkas værk. Men i og omkring denne figur lader en særlig litterær bevægelighed og Witz sig se - ikke mindst i form af en freudiansk vits, der muligvis ikke er strikt forbundet med det ubevidste i den sædvanlige forstand.

I anledning af en korrekturlæsning af fortællingen i februar måned 1913 beslutter Kafka at nedskrive alle de „Beziehungen“ i og omkring Das Urteil, som han er blevet bevidst om siden affattelsen af teksten:

Dette er nødvendigt, for historien [die Geschichte] er kommet ud af mig som en regelret fødsel, dækket med smuds og slim, og kun jeg har hånden, der kan trænge frem til kroppen, og har lyst dertil...(GW, bd. 10. Tagebücher 1912-1914, p. 125)

Fødselsmetaforen er en noget mærkværdig figur at frembringe i relation til en Geschichte, der fortæller historien om en søn dømt til døden af sin fader. Hvordan kunne man forestille sig oprindelsen til denne fødsel? Antagelig som en ubesmittet, men meget beskidt undfangelse, hvis udbytte er et egenartet selvmord i form af en tekst. Dommen er som fortælling et barn født af forfatteren, og det er en tekst $\mathrm{i}$ hvilken forfatteren etablerer rummet for et korresponderende alter egos død, for derved at omskrive et punkt hinsides faderens figur, hvor litteratur kan finde sted. Das Urteil er, anderledes betragtet, Kafkas eget, og i en ejendommelig forstand bliver forfatteren, via denne dom, sin egen fader, idet han, som ophav, lader en søn gå til grunde i et univers dækket af en tilsyneladende overvældende faders billede.

I det dagbogsnotat, der følger umiddelbart efter Das Urteil i det hæfte, hvori Kafka nedskrev fortællingen - og som i øvrigt er en refleksion af selve den skriveproces, der varede otte timer en nat sent i september 1912 -, bemærker forfatteren, at "Gedanken an Freud ${ }^{\prime \prime} 7$ falder ham naturligt i tilknytning til Dommen. Fortællingen er ét omfattende felt for udveksling og kamp mellem faderen og sønnens positioner, og derfor netop $i$ høj grad naturligt åben for tanker vedrørende Freud. Relationerne og kampene mellem fader og søn er i Das Urteil konstant i centrum for de tekstuelle forvandlinger - og bliver gentagne gange reflekteret $\mathrm{i}$ tilsyneladende mindre omvendinger af det sædvanlige hierarki: efterhånden som fortællingen udfoldes, lader det således til, at Georg Bendemann bliver sin egen faders fader, og som sådan dels må bemærke ophavets barnligt urene undertøj, dels foreslå, at de bytter værelser - symbolske rum, i et videre perspektiv -, og at faderen derfor lægger sig i hans, Georgs, seng. Undervejs i disse inversioner i de familiære roller og lokaliteter, bærer Georg sin fader til sengs i en retarderende bevægelse:

På sine arme bar han faderen i seng. En skrækkelig følelse havde han, da han i løbet af de par skridt hen til sengen mærkede, at faderen legede med urkæden på hans bryst [dass an seiner Brust der Vater mit seiner Uhrkette spiele]. Han kunne ikke straks lægge ham i seng, så fast hold han sig i denne urkæde. (GW, bd. 1: Ein Landarzt und andere Drucke $z u$ Lebzeiten, p. 48)

Et særpræget moment i den freudianske konception af de ødipale udvekslinger mellem fader og søn, er tendensen til at forblive fikseret på den forestillede sønlige angst $\mathrm{i}$ tilknytning til faderen. ${ }^{8}$ Ingen mulig angst fra faderens side synes at være på færde, eller i det mindste at blive reflekteret - og da slet ikke en mulig angst vedrørende fremtidig udskiftning: at faderen som 
sådan kunne gå under i sit afkom, og sønnen dermed overtage hans plads. En faderlig angst, med andre ord, knyttet til muligheden for at sønnen kunne - skal - blive sin egen fader og herre, og på den vis etablere en position, hvorfra andre sønner - og andre fortællinger - kunne udspringe.

Idet Georg Bendemann søger at lægge sin fader i seng, bliver han ramt af en skrækkelig følelse, da han bemærker, at faderen som et barn leger med den urkæde, der er fastgjort til Georgs bryst, ja, egentlig ikke kun leger med den, men griber den så fast, at Georg bliver forsinket i sin bevægelse. At faderen holder hårdt fast i sønnens urkæde, vil på den ene side sige, at han hænger sig $i$ leddet til det, der udmåler faderen og sønnens tid i et før og et efter, og dermed ligeledes indicerer, at når nogen lægger noget og nogen bag sig - eller bort -, er der nogen og noget, der bliver ladt tilbage - til eksempel i deres søns seng.

Men dette er igen en historie, der altid rækker længere tilbage: det er ret beset, via et ordspil omkring et stumt $h$, i sig selv en $U r$ Kette, en Ur-kæde, af udvekslinger og relationer i sammenknytning og ophævelse. Som sådan ligger den hinsides, eller før, enhver konkret tid og enhver konkret forbindelse. Det er helt uomtvisteligt Georg Bendemanns urkæde, som faderen leger med og hænger sig fast $i$, $i$ en situation og interageren, der på den facon er fuldstændig enestående. Men på den anden side: dette har altid allerede fundet sted, eftersom fædre har sønner, og den ene kæde dermed reflekteres i den anden.

Dette kompleks vækker mindelser om en anden paradoksal fiktion, der, for overhovedet at kunne konciperes, må tænkes som betegnende et scenario, der på én gang altid er set før, er en evig gentagelse, og en partikulær, markant enestående, begivenhed: psykoanalysens Urszene: 9 barnets syn og et barns syn, der kun kan spores i dets traumatiske effekter i seksualitetens udfoldelse.

En bemærkelsesværdig humor ser da ud til at bevæge sig igennem de læsende "Gedanken an Freud" i Kafkas fortælling: en læsning der måske kunne kaldes en parodisk invers gentagelse af det uigentagelige, der ikke kan undgå at blive gentaget: $i$ Georg Bendemanns Uhrkette er en Urkette uhørligt involveret, og fortællingen præsenterer sig som Das Urteil. Eine Geschichte. Substantivet Urteil kan ikke blot betyde dom eller vurdering, men ligeledes ur-del, et stofs fundamentale komponent, og derfor vedrøre betragtninger om grund og begrundelse i et filosofisk perspektiv: ${ }^{10}$ ideen om en primær $U r$-teil og en oprindelig $U r$-teilung; en Ur-teilung, der er såvel en opsplitning i grundlæggende bestanddele som en primordial deling.

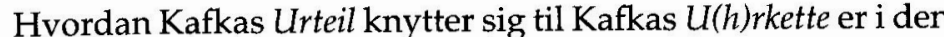
sammenhæng interessant at følge: en urkæde, med alle dens konnotationer i denne kontekst, består $i$ og af sine egne indre forbindelser af dele eller led, der svarer til hinanden uden, qua netop enkelte led, at være fuldt og helt identiske, og som gentager hverandre uden at gentage hverandre - ikke helt ulig K'er i skrift. Eftersom hvert led præcis er et led, kan ingen $U(h) r k e t t e ~ s i-$ ges at besidde definérbare Urteile: der gives faktisk ikke noget urokkeligt og primært før og efter, men altid en stadig mulighed for inversioner, hvor det ene led, reflekterende, træder i stedet for det andet $i$ et udvekslingsspil, der ikke tillader nogen enestående Urteil - $\mathrm{i}$ alle juridiske og filosofiske betydninger af ordet - at være den ultimativt første og/eller definitivt sidste. I Kafkas 'Urszene' bliver det uigentagelige i den enkeltes tid således præsenteret $i$ form af en principielt uendelig gentagelse, der giver sig til kende som vedvarende omskiftelighed i stedfortrædelsens modus: som søn, så fader, idet den første skal blive den sidste - og vice versa. Intet enkelt led og ingen autoritær magt, Fader, eller dømmende instans, kan dermed restløst kontrollere eller gribe denne litterære skriven, som skriven. På altid forskellig vis at citere sit eget navn - og lade sig markere som sin egen litteraturs bogstav - er i sidste ende måske ikke mindst at sætte dét - og blive fremstillet som endnu ikke defineret, altid undervejs, og hinsides faderens greb - og i særdeleshed hinsides kontrol for den Vater, der beordrede sin søns litteratur placeret ved siden af sin seng: „Læg den på natbordet!", som Hermann Kafka sagde, da han blev konfronteret med en del af sønnens skrifter. 


\section{Noter}

1. "Jeg har ingen litterær interesse, men består af litteratur, jeg er ikke andet og kan ikke være andet.". (Franz Kafka: Briefe an Felice, Frankfurt a.M., 1983, p. 444). Med mindre andet er anført, er citater - angivet med bind og sidetal - fra Franz Kafka: Gesammelte Werke in zwolj Banden; Koch, Hqns-Gerd (udg.), Frankfurt a.M., 1994 (GW). Alle oversættelser er mine egne.

De her berørte betragtninger stammer i øvrigt fra Kafkas dagbøger og lyder i en større sammenhæng: ,Jeg kan ikke forstå det og ikke engang tro det.. Jeg lever blot hist og her i et lille ord i hvis omlyd ...jeg f.eks. på et øjeblik taber mit unyttige hovede." (bd. 9: Tagebiicher 1909-1912, p. 33-34); "..hvis det var nok at sætte et ord hen og man kunne vende vende sig bort, i den rolige bevidstbed om fuldstændig at have fyldt dette ord med sig selv." (ibid., p. 110); "Ville jeg engang kunne skrive et større hele, veldannet fra begyndelsen til slutningen, da kunne historien [die Geschiahte] ejheller nogensinde løsgøre sig endegyldigt fra mig og jeg ville have lov til, som blodsbeslægtet med en sund historie, roligt og med åbne øjne at lytte til dens oplæsning ..." (ibid., p. 177).

Franz: Kafkas særlige selvfiguration - at han består af og i litteratur. kunne også foranledige en anden betragtning af værkets fragmentariske gestaltning og udfoldelse: hvordan færdiggøre og fuldende det, man er, for sig selv, og uden om sig selv? Denne Kafkas forestillede varen litteratur er, overordnet, rammen for de følgende siders læsping.

2. Cfr. Roland Barthes: Le90n, Paris, 1989, p. 46

3. Denne form for refleksion i Kafkas værk skal her forstås i relation til Benjamins teatralske og epistemologiske begreb om Darstellung - en stillen frem og fremstilling - som prcesentation snarere end repræsentation: darstellen er at vise, ikke at kommunikere (direkte) (Se hertil: Walter Benjamin: Ursprung des deutschen Trauerspials (Erkenntniskritische Vorrede), Frankfurt a.M., 1990; Hans-Jost Frey: On Presentation in Benjamin in: David S.Ferris (red.): Walter Benjamin. Theoretical Questions, Stanford, 1996). 4. GW, bd. 9: Tagebiicher 1909-1912, p. 263.

5. GW, bd. 4: DasSchloss, p. 9

6.Cfr. Walter Benjamin: Ursprung des deutschen Trauerspiels, Frankfurt a.M., 1990, p. 28.

7. GW, bd. 10: Tagebiicher 1912-1914, p. 101

8. Cfr. Thomas Adam Pepper: Singularities. Extremes af theory in the twentieth century, Cambridge, 1997,p. 41.

9. Denne teoretiske forestilling spillede en ikke helt. uvæsentlig rolle for Freud i tiden efter udgivelsen af Studien iiber Hysterie i 1895. I $\emptyset v$ rigt kunne man måske, med et udtryk fra Freuds Der Wifz und seine Beziehung zum Unbewussten, fra 1905, betegne Kafkas vitsteknik i Dommen som en "Verdichtung mit leichter Modifikation" (Der Witz ..., Frankfurt a.M., 1991, p. 20).

10. Som hos eksempelvis Friedrich H6lderlin i det lille fragment Urtheil und Seyn fra 1795 (Se hertil Jørn Erslev Andersen: Grundens forvitringidealistisk romantik hos Fichte og Holderlin in: At gå til grunde; Mai, AnneMarie og Walther, Bo Kampmann (red.), Odense 1997. 